\title{
Examining Effects of Worksheets to Associate Thermodynamics Concepts with Related Daily Events
}

\author{
Güner TURAL *, Özge KOL \\ Secondary Science and Mathematics Education, Ondokuz Mayıs University, Samsun, Turkey
}

\begin{abstract}
The objective of this study is to examine the effect of worksheets as a tool used for teacher candidates to associate thermodynamics concepts with related daily events in an active learning environment. A questionnaire that consists of eight open-ended questions was developed by the researchers. The content of these questions was relationship of zeroth and first laws of thermodynamics and expansion concept with daily events. This measurement tool was applied to fifteen fourth year physics teacher candidates in the Black Sea Region of Turkey during the 2014-2015 academic years before and after the application. Answers of the physics teacher candidates to questionnaire were analyzed via understanding level criterions as sound understanding, partial understanding, misunderstanding and no understanding. Three worksheets contain hands-on activities were applied in four-hour lesson. After completion of questionnaire the interview was implemented about teacher candidates'opinions related to application. The results of questionnaire showed that after application there was an increase for sound and partial understanding. After application of worksheets, teacher candidates were able to use zeroth and first laws of thermodynamics and expansion concept in daily events more easily. It was concluded that worksheets enhanced teacher candidates' understanding relationship of zeroth and first laws of thermodynamics and expansion concept with daily events. Also they provided active learning environment to teacher candidates.
\end{abstract}

Keywords: thermodynamics; worksheets; daily events; physics teacher candidates

\section{INTRODUCTION}

We encounter with many applications of thermodynamics in working principles of many machines and in many events of our lives. However previous studies (Avezedo e Silva, 1991; Cotignola, Bordogna, Punte, \& Cappannini, 2002; Pintó, Couso, \& Gutierrez, 2005; Tatar \& Oktay, 2011) pointed out students have problems such as conceptual or associating with daily life in thermodynamics. Learners generally have a feeling that thermodynamics is the most difficult subject (Ishida \& Chuang, 1997). This may be due to the rather abstract concepts in thermodynamics. In order to enhance the teaching and learning of thermodynamics, researchers (Junglas, 2006; Mulop, Yusof, \& Tasir, 2012; Pintó, Couso, \& Gutierrez, 2005; Tatar \& Oktay, 2011) suggest different teaching approaches from traditional approach. Active learning approaches can help to overcome these problems and can enhance

Assoc. Prof. Dr. e-mail: guner.tural@omu.edu.tr 
students' conceptual understanding as indicated in many studies (Akınoğlu \& Özkardeş Tandoğan, 2007; Etherington, 2011; Karamustafaoğlu, Coştu, \& Ayas, 2006). Worksheets are one of the instructional material that make the students active in learning environment. Worksheets are defined as important material that contain process steps relating to students should do, help students to construct their knowledge in their minds and allow to whole class participate to activities (Sands \& Özçelik, 1997; YÖK, 1998). Worksheets can be used to improve students' request to the course, to eliminate the misconceptions about a particular topic or for the purpose of teaching a new subject (Atasoy \& Akdeniz, 2006). Gönen and Akgün (2005) investigated applicability of worksheet associated with relationship between heat and temperature concepts. They developed a worksheet and applied to science student teachers. According to results, the worksheet helped science student teachers to improve appropriate understandings related to topic.

It is stated that worksheets ensure students to develop positive attitude towards the natural sciences if they include experiments that can be done with simple and inexpensive tools (Kurt \& Akdeniz, 2002). Bozdoğan (2007) examined the effects of worksheets on the logical thinking and the attitude of the students on the education of science. To measure the attitude of the students against science, "Attitude Scale Towards Science" was exercised both control and experiment group students. It was found significant difference in favor of experiment group students that were educated with worksheets.

In this research, it was aimed to examine the effect of worksheets to associate teacher candidates' thermodynamics concepts with daily events in an active learning environment.

\section{METHOD}

\section{Participants}

The participants of the study consists of fifteen fourth year physics teacher candidates from Department of Secondary Science and Mathematics Education in one of the Black Sea Region universities in Turkey.

\section{Data collection tools}

A questionnaire consists of eight open-ended questions was developed by the researchers. The content of these questions was relationship of zeroth and first laws of thermodynamics and expansion concept with daily events. One of the questions from questionnaire was given below.

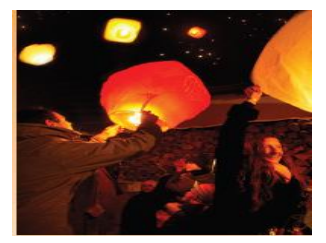

How does a wish lantern work? Please explain.

Figure 1. A question from questionnaire

Also structured interview was implemented about teacher candidates'opinions related to application. Interview questions were as follows: Q1. Please compare the effects of previous 
teaching method and current teaching method of thermodynamics in terms of comprehending the subject. Q2. How did the worksheets you used in the class contribute you to associate the laws of thermodynamics with daily life? Please explain by giving examples.

\section{Analysis of data}

To analyze teacher candidates' responses, the following criterions (Table 1) similar to a rubric developed by Abraham, Williamsom, and Wetsbrook (1994) were employed.

Table 1. Criteria used in the evaluation of the open-ended questions

\begin{tabular}{lc} 
Understanding Level & Shortenings \\
\hline Sound Understanding: Responses containing all components of the scientifically accepted response & SU \\
$\begin{array}{lc}\text { Partial Understanding: Responses that included at least one of the components of validated response, } \\
\text { but not all the components }\end{array}$ & PU \\
Misunderstanding: Scientifically incorrect responses containing illogical or incorrect information & MU \\
No Understanding: Blank, repeats question; irrelevant or unclear response & NU \\
\hline
\end{tabular}

\section{Application}

Firstly prior to the instruction the questionnaire was administered to all participants. They enrolled introductory physics and thermodynamics courses before this study. So they have concepts and laws of thermodynamics. But these courses were in traditional manner. This teaching sequence is formed by memorization-based learning of concepts, laws and practice standard problems. After examining students' answers and finding out the conceptual problems, three worksheets were developed by the researchers to enhance conceptual understanding. These worksheets were prepared according to Predict- Observe- Explain (POE) strategy was developed by White and Gunstone (1992) to find out students' predictions, and their reasons for making these, about a specific event. One of the worksheets was given in appendix. The researcher designed four hour lesson and applied worksheets contain hands-on activities. Teacher candidates had concrete experiences. They performed activities in groups and were given opportunity to discuss events. So they were active in the learning environment. At the end of the last lesson, questionnaire was administered to teacher candidates again. And after completion of questionnaire the interview was implemented about their opinions related to application.

\section{FINDINGS}

\section{Findings from questionnaire}

The analysis of the collected data from questionnaire was completed question-byquestion and findings were presented in Table 2. 
Table 2. Answers to pre-test and post-test according to understanding levels

\begin{tabular}{|c|c|c|c|c|c|c|c|c|}
\hline \multirow[t]{3}{*}{$\begin{array}{l}\text { Question } 1 \\
\text { The reason for } \\
\text { using water instead } \\
\text { of mercury in } \\
\text { thermometers }\end{array}$} & \multicolumn{2}{|c|}{$\begin{array}{l}\text { SU } \\
\text { It is benefited from } \\
\text { mercury's low } \\
\text { expansion coefficient } \\
\text { quality in comparison to } \\
\text { other liquids. If water } \\
\text { were used a longer pipe } \\
\text { would be needed. }\end{array}$} & \multicolumn{2}{|c|}{$\begin{array}{l}\text { PU } \\
\text { Mercury is used due to } \\
\text { specific heat of } \\
\text { expansions of mercury } \\
\text { and water. }\end{array}$} & \multicolumn{2}{|c|}{$\begin{array}{l}\text { MU } \\
\text { It is used because of } \\
\text { density differences, } \\
\text { boiling and freezing } \\
\text { point and its density. }\end{array}$} & \multicolumn{2}{|c|}{ NU } \\
\hline & Pre-test & Post-test & Pre-test & Post-test & Pre-test & Post-test & Pre-test & Post-test \\
\hline & 2 & 10 & 2 & 2 & 12 & 2 & - & 1 \\
\hline \multirow[t]{3}{*}{$\begin{array}{l}\text { Question } 2 \\
\text { The way how the } \\
\text { jar lids are loosened } \\
\text { by being kept under } \\
\text { hot water }\end{array}$} & \multicolumn{2}{|c|}{$\begin{array}{l}\text { SU } \\
\text { Jar lid expands by being } \\
\text { kept under hot water. } \\
\text { The temperature of the } \\
\text { heated lid increases and } \\
\text { this makes the metal lid } \\
\text { expand. The volume of } \\
\text { the expanded lid } \\
\text { increases and it is } \\
\text { opened. }\end{array}$} & \multicolumn{2}{|c|}{$\begin{array}{c}\text { PU } \\
\text { The heated lid expands. }\end{array}$} & \multicolumn{2}{|c|}{$\begin{array}{l}\text { MU } \\
\text { The heated jar expands. } \\
\text { The pressure of the jar } \\
\text { which is kept under hot } \\
\text { water increases } \\
\text { therefore the lid is } \\
\text { opened. }\end{array}$} & \multicolumn{2}{|c|}{$\mathbf{N U}$} \\
\hline & Pre-test & Post-test & Pre-test & Post-test & Pre-test & Post-test & Pre-test & Post-test \\
\hline & 6 & 13 & 3 & 1 & 6 & - & - & 1 \\
\hline \multirow[t]{3}{*}{$\begin{array}{l}\text { Question } 3 \\
\text { Whether or not } \\
\text { contradict staying } \\
\text { warm by wearing } \\
\text { woolen sweaters in } \\
\text { cold weather with } \\
\text { the laws of } \\
\text { thermodynamics }\end{array}$} & \multicolumn{2}{|c|}{$\begin{array}{l}\text { SU } \\
\text { We choose clothes } \\
\text { which will reduce the } \\
\text { velocity of the flow of } \\
\text { energy in order to } \\
\text { maintain our body } \\
\text { temperature. } \\
\text { We wear thick clothes. } \\
\text { As the thickness of the } \\
\text { material increases the } \\
\text { velocity of energy } \\
\text { transfer decreases. It } \\
\text { does not contradict with } \\
\text { the laws of } \\
\text { thermodynamics. }\end{array}$} & \multicolumn{2}{|c|}{$\begin{array}{l}\text { PU } \\
\text { The sweater provides } \\
\text { insulation, so we keep } \\
\text { our temperature. }\end{array}$} & \multicolumn{2}{|c|}{$\begin{array}{l}\text { MU } \\
\text { Yes, it contradicts with } \\
\text { the laws. Because, we } \\
\text { should be in thermal } \\
\text { equilibrium via outside } \\
\text { temperature }\end{array}$} & \multicolumn{2}{|c|}{$\mathbf{N U}$} \\
\hline & Pre-test & Post-test & Pre-test & Post-test & Pre-test & Post-test & Pre-test & Post-test \\
\hline & 2 & 9 & 4 & 4 & 6 & 2 & 3 & - \\
\hline
\end{tabular}




\begin{tabular}{|c|c|c|c|c|c|c|c|c|}
\hline \multirow[t]{3}{*}{$\begin{array}{l}\text { Question } 4 \\
\text { The working } \\
\text { principle of wish } \\
\text { lantern }\end{array}$} & \multicolumn{2}{|c|}{$\begin{array}{l}\text { SU } \\
\text { Expansion of air is } \\
\text { supplied by being } \\
\text { heated with the candle. } \\
\text { Expanded air inflates } \\
\text { the lantern by rising in } \\
\text { cold air which is } \\
\text { heavier than the } \\
\text { expanded air and the } \\
\text { wish lantern rises. }\end{array}$} & \multicolumn{2}{|c|}{$\begin{array}{l}\text { PU } \\
\text { Heated air expands and } \\
\text { its volume increases by } \\
\text { its expansion. }\end{array}$} & \multicolumn{2}{|c|}{$\begin{array}{l}\text { MU } \\
\text { We must apply force on } \\
\text { the material in order to } \\
\text { move it. The lantern is } \\
\text { raised by the applied } \\
\text { force on it. }\end{array}$} & \multicolumn{2}{|c|}{$\mathbf{N U}$} \\
\hline & Pre-test & Post-test & Pre-test & Post-test & Pre-test & Post-test & Pre-test & Post-test \\
\hline & 1 & 5 & 1 & 4 & 11 & 5 & 2 & 1 \\
\hline \multirow[t]{3}{*}{$\begin{array}{l}\text { Question } 5 \\
\text { The reason for } \\
\text { leaving gaps } \\
\text { between tiles }\end{array}$} & \multicolumn{2}{|c|}{$\begin{array}{l}\text { SU } \\
\text { Materials' volume } \\
\text { increases by the } \\
\text { changes in their } \\
\text { temperature as a result } \\
\text { of the energy exchange. } \\
\text { In other words, it } \\
\text { expands. Considering } \\
\text { that, gaps are left } \\
\text { between tiles. }\end{array}$} & \multicolumn{2}{|c|}{$\begin{array}{l}\text { PU } \\
\text { Because it is considered } \\
\text { that the tiles will } \\
\text { exchange energy with } \\
\text { their environment. }\end{array}$} & \multicolumn{2}{|c|}{$\begin{array}{l}\text { MU } \\
\text { It is tried to fasten the } \\
\text { tile to floor and to } \\
\text { reduce heat exchange as } \\
\text { using fillers. }\end{array}$} & \multicolumn{2}{|c|}{$\mathbf{N U}$} \\
\hline & Pre-test & Post-test & Pre-test & Post-test & Pre-test & Post-test & Pre-test & Post-test \\
\hline & 6 & 7 & 1 & 1 & 7 & 6 & 1 & 1 \\
\hline \multirow[t]{3}{*}{$\begin{array}{l}\text { Question 6 } \\
\text { The reason why } \\
\text { Eiffel Tower is not } \\
\text { damaged although } \\
\text { it is expanded in } \\
\text { hot weather. }\end{array}$} & \multicolumn{2}{|c|}{$\begin{array}{l}\text { SU } \\
\text { Gaps are left between } \\
\text { ports in large steel } \\
\text { structures and buildings } \\
\text { in order to remove the } \\
\text { negative effects of } \\
\text { expansion. Therefore, it } \\
\text { is not damaged. }\end{array}$} & \multicolumn{2}{|c|}{$\begin{array}{l}\text { PU } \\
\text { The materials of which } \\
\text { expansion is less can be } \\
\text { selected. } \\
\text { There are engineering } \\
\text { calculations taking } \\
\text { expansion into account }\end{array}$} & \multicolumn{2}{|c|}{$\begin{array}{l}\text { MU } \\
\text { It is kept in thermal } \\
\text { equilibrium and } \\
\text { expansion does not } \\
\text { exist. Heat is kept } \\
\text { constant. }\end{array}$} & \multicolumn{2}{|c|}{ NU } \\
\hline & Pre-test & Post-test & Pre-test & Post-test & Pre-test & Post-test & Pre-test & Post-test \\
\hline & 3 & 4 & 1 & 5 & 10 & 4 & 1 & 2 \\
\hline
\end{tabular}




\begin{tabular}{|c|c|c|c|c|c|c|c|c|}
\hline \multirow[t]{3}{*}{$\begin{array}{l}\text { Question } 7 \\
\text { How Eskimos live } \\
\text { in igloos without } \\
\text { freezing }\end{array}$} & \multicolumn{2}{|c|}{$\begin{array}{l}\text { SU } \\
\text { Snow and ice are good } \\
\text { heat insulators. The } \\
\text { gaps between the ice } \\
\text { blocks by which the } \\
\text { igloos are built are } \\
\text { plastered by using } \\
\text { snow. Layer of snow } \\
\text { provides sufficient heat } \\
\text { insulation. }\end{array}$} & \multicolumn{2}{|c|}{$\begin{array}{l}\text { PU } \\
\text { They can live since the } \\
\text { outside air (wind etc.) } \\
\text { protects them }\end{array}$} & \multicolumn{2}{|c|}{$\begin{array}{l}\text { MU } \\
\text { The subject here is } \\
\text { adaptation. They adapt } \\
\text { to their environment. }\end{array}$} & \multicolumn{2}{|c|}{$\mathbf{N U}$} \\
\hline & Pre-test & Post-test & Pre-test & Post-test & Pre-test & Post-test & Pre-test & Post-test \\
\hline & 7 & 10 & 3 & 3 & 2 & 2 & 3 & - \\
\hline \multirow[t]{3}{*}{$\begin{array}{l}\text { Question } 8 \\
\text { How a metal sphere } \\
\text { passes through the } \\
\text { ring when the ring } \\
\text { is heated }\end{array}$} & \multicolumn{2}{|c|}{$\begin{array}{l}\text { SU } \\
\text { The atoms of the heated } \\
\text { ring move faster and } \\
\text { diverge from one } \\
\text { another (expand). Its } \\
\text { volume increases due to } \\
\text { expansion. So, the } \\
\text { sphere passes through } \\
\text { the ring. }\end{array}$} & \multicolumn{2}{|c|}{$\begin{array}{l}\text { PU } \\
\text { The sphere passes } \\
\text { through the ring due to } \\
\text { expansion. }\end{array}$} & \multicolumn{2}{|c|}{$\begin{array}{l}\text { MU } \\
\text { It loses energy, the } \\
\text { sphere gets smaller. }\end{array}$} & \multicolumn{2}{|c|}{$\mathbf{N U}$} \\
\hline & Pre-test & Post-test & Pre-test & Post-test & Pre-test & Post-test & Pre-test & Post-test \\
\hline & 10 & 10 & 2 & 4 & 3 & 1 & - & - \\
\hline
\end{tabular}

SU: Sound Understanding, PU: Partial Understanding, MU: Misunderstanding, NU: No Understanding

As can be seen from Table 2, scientifically full correct responses of teacher candidates increased after application except for question 8. Samely, scientifically incorrect responses containing illogical or incorrect information of teacher candidates decreased. One answer rising in no understanding level for question 6 is based on not answering the question of one teacher candidate.

\section{Findings from interview}

Q1. Please compare the effects of previous teaching method and current teaching method of thermodynamics in terms of comprehending the subject.

Teacher candidates stated that, the application provided to make abstract concepts concrete, to discuss and better understanding the thermodynamics concepts, visualization and permanent learning. The excerpts from the teacher candidates relating to these opinions as follows:

"We learned the laws of thermodynamics via observation, so the concepts turned into concrete from abstract." (S1)

"We learned the subject with lecture method before. We could not connect it to real life. Now we did practices with worksheets. We discussed concepts. In addition, we made it visually 
permanent by creating hands-on activities environment in the class." (S2)

"Such a learning method expanded our horizons about thermodynamics. We learned concepts such as heat transmission and thermal equilibrium by experience." (S4)

"This application helped a lot. For example, it helped me to understand thermodynamics subject better. And I realize that I did not know many concepts correctly before. "(S5)

"I think previous theoretically teaching which consists of formulas is not useful. I think the subject taught by practices like that is more permanent for us." (S14)

"Since we did not learn by simplifying it before. So, we could not picture daily life using of thermodynamics in our minds. It has been a memorable subject as we did practices." (S15)

Q2. How did the worksheets you used in the class contribute you to associate the laws of thermodynamics with daily life? Please explain by giving examples.

About contributions of worksheets on associating the laws of thermodynamics with daily life, teacher candidates stated that, worksheets ensured positive effect. The excerpts from the teacher candidates relating to these opinions as follows:

"We remembered the forgetten concepts by doing experiments. The energy transmission between the hammer and the nail was the most notable one. I noticed that when we hammered the nails into the wood it got heated but I did not know the reason. I learned that we come across the laws of thermodynamics in our daily life without noticing them." (S3)

" I constantly questioned for what purpose we will use these laws and whether they were used in daily life. But, the formulas no longer made sense in my mind." (S9)

"We learned how thermodynamics is used in daily life thanks to the practices we did here. For example; we learned how the buildings are isolated by using insulating materials." (S14)

"We learned this subject before theoretically. We experienced whether the ideas we put forward were correct or not. Thus, we learned more permanent information. For example in the first worksheet, we observed thermal equilibrium by practicing the zeroth law of thermodynamics." (S15)

\section{DISCUSSION and CONCLUSION}

The present study examined effect of worksheets to associate teacher candidates' thermodynamics concepts with daily events in an active learning environment.

Before application teacher candidates' answers showed that they had problems to associate thermodynamics concepts with daily events. Their answers mostly contained misunderstanding. After worksheets application in the lesson, teacher candidates were able to use zeroth and first laws of thermodynamics and expansion concept in daily events more easily. Their scientifically full correct responses increased and non-scientific responses containing illogical or incorrect information decreased. Samely, study of Gönen and Akgün (2005) about applicability of worksheet associated with relationship between heat and temperature concepts showed worksheet helped the science student teachers to improve 
appropriate understandings about topic. Also various studies (Atasoy, 2008; Burhan, 2008; Coştu, Karataş, \& Ayas, 2003; Demircioğlu, Demircioğlu, \& Ayas, 2004) concluded that worksheets were effective to change the students' misconceptions into scientific conceptions and had positive contribution to concept learning.

Opinions of teacher candidates about current application in comparison with previous traditional one were positive in favour of application with worksheets. Such an application ensured teacher candidates to be active in learning process. They stated the application with worksheets contain hands-on activities provided them to make abstract concepts concrete, to discuss and better understanding the thermodynamics concepts, to associate the laws of thermodynamics with daily life, visualization and permanent learning. Teacher candidates' opinion about better understanding the concepts via worksheet application is consistent with study of Turan (2012) that determined effects of worksheets on academic success for unit "Force and Motion" at the 8th grade.

The results of the study are valid for the study group who participated in present study. And the study doesn't intend to generalize the results to a larger universe. A similar study is suggested to conduct by researchers from different universities.

\section{Appendix: One of the worksheets}

\section{WORKSHEET}

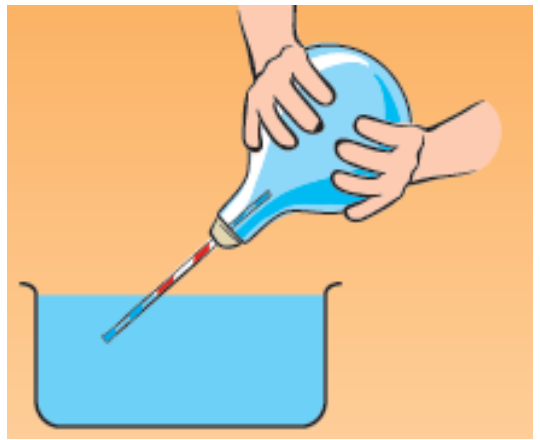

What kind of results do you expect to meet when you heat the volumetric flask after plunging it into a container of water with the help of a glass pipe?

Let's answer this question via an activity:

- Materials: Volumetric flask, glass tube, holey cork, container, water

- Procedure:

(1) Plug the hollow cork up the volumetric flask.

(2) Pass the glass pipe through the holey cork.

(3) Plunge the tube end into the water.

(4) Heat the underneath of the volumetric flask using your hand and observe the water carefully.

1. What did you observe in the water?

2. If you had kept heating the volumetric flask with your hands, would there have been any changes in your observations? Why? 
3. What kind of changes will there be if we use a heater like spirit stove instead of our hands? Please explain with reasons.

- Do your current opinions consistent with the previous ones that before conducting the experiment? If it is not, what does your mistake result from? Please explain.

\section{References}

Abraham, M. R., Williamsom, V. M., \& Wetsbrook, S. L. (1994). A cross-age study of the understanding of five chemistry concepts. Journal of Research in Science Teaching, $31(2), 147-165$.

Akınoğlu, O., \& Özkardeş Tandoğan, R. (2007). The effects of problem-based active learning in science education on students' academic achievement, attitude and concept learning. Eurasia Journal of Mathematics, Science \& Technology Education, 3(1), 7181.

Atasoy, Ş. (2008). Öğretmen adaylarının Newton'un hareket kanunları konusundaki kavram yanılgılarının giderilmesine yönelik geliştirilen çalışma yapraklarının etkililiğinin araştırılması. (Unpublished Ph. D. thesis). Karadeniz Technical University, Trabzon, Turkey.

Atasoy, Ş., \& Akdeniz, A. R. (2006.) Yapılandırmacı öğrenme kuramına uygun geliştirilen çalışma yapraklarının uygulama sürecinin değerlendirilmesi. Milli Ĕ̆itim Dergisi, 35 (170), 157-175.

Avezedo e Silva, J. F. M. (1991). The thermodynamics of a refrigeration system. Physics Education, 26, 115-119.

Bozdoğan, A. (2007). Fen bilgisi ögrretiminde çalışma yapraklarl ile öğretimin öğrencilerin fen bilgisi tutumuna ve mantıksal düşünme becerilerine etkisi. (Unpublished master's thesis). Çukurova University, Adana, Turkey.

Burhan, Y. (2008). Asit ve baz kavramlarına yönelik karikatür destekli çalışma yapraklarının geliştirilmesi ve uygulanması (Unpublished master's thesis). Karadeniz Technical University, Trabzon, Turkey.

Coştu, B., Karataş, F.Ö., \& Ayas, A. (2003). Kavram öğretiminde çalışma yapraklarının kullanılması. Pamukkale Üniversitesi Eğitim Fakültesi Dergisi, 2(14), 33-48.

Cotignola, M. I., Bordogna, C., Punte, G., \& Cappannini, O. M. (2002). Difficulties in learning thermodynamic concepts: Are they linked to the historical development of this field? Science \&Education, 11, 279-291.

Demircioğlu, H.; Demircioğlu, G., \& Ayas, A. (2004). Kavram yanılgılarının çalışma yapraklarıyla giderilmesine yönelik bir çalışma. Milli Ĕ̆itim Dergisi, 163.

Etherington, M. B. (2011). Investigative primary science: A problem-based learning approach. Australian Journal of Teacher Education, 36(9), 53-74.

Gönen, S. \& Akgün, A. (2005). The investigation of applicability of worksheet was developed about relationship between heat and temperature concepts. Elektronik Sosyal Bilimler Dergisi, 3(11), 92-106.

Ishida, M., \& Chuang, C. (1997). New approach to thermodynamics. Energy Conversion and Management, 38(15-17), 1543-1555.

Junglas, P. (2006). Simulation programs for teaching thermodynamics, Global Journal of Engineering Education, 10(2) 175-180. 
Karamustafaoğlu, S., Coştu, B. \& Ayas, A. (2006). Turkish chemistry teachers' views about an implementation of the active learning approaches in their lessons. Asia-Pacific Forum on Science Learning and Teaching, 7(1).

Kurt, Ş., \& Akdeniz, A.R., (2002). Fizik öğretiminde enerji konusunda geliştirilen çalışma yapraklarının uygulanması. V. Ulusal Fen Bilimleri Matematik Eğitimi Kongresi, ODTÜ, Ankara.

Mulop, N., Yusof, K. M., \& Tasir, Z. (2012). A review on enhancing the teaching and learning of thermodynamics. Procedia - Social and Behavioral Sciences, 56, 703-712.

Pintó, R., Couso, D., \& Gutierrez, R. (2005). Using research on teachers' transformations of innovations to inform teacher education: The case of energy degradation. Science Education

89 (1), 38-55.

Sands, M., \& Özçelik, D. A. (1997). Okullarda uygulama çalışmaları. Öğretmen Eğitimi Dizisi, Yök/Dünya Bankası Milli Eğitimi Geliştirme Projesi, Hizmet Öncesi Öğretmen Eğitimi, Ankara: YÖK Yay.

Tatar, E., \& Oktay, M (2011). The effectiveness of problem-based learning on teaching the first law of thermodynamics. Research in Science \& Technological Education, 29(3), 315-332.

Turan, G. (2012). 8. sınıf kuvvet ve hareket ünitesinin ögretiminde çalışma yapraklarının ögrencilerin başarılarına etkisi. (Unpublished master's thesis). Adıyaman University, Adiyaman, Turkey.

White, R. T., \& Gunstone, R. F. (1992). Probing Understanding. Great Britain: Falmer Press YÖK. (1998). Fakülte-okul işbirliği kılavuzu. Öğretmen Eğitimi Dizisi, YÖK/Dünya Bankas1 Milli Eğitimi Geliştirme Projesi, Hizmet Öncesi Öğretmen Eğitimi, Ankara: YÖK Yay. 